\title{
WHAT ARE THE POTENTIAL WAYS TO SOLVE THE ISSUE OF PROFESSIONALIZATION OF RISK BEHAVIOUR PREVENTION IN SCHOOL ENVIRONMENT?
}

\author{
Václav Bělík
}

\begin{abstract}
The submitted article addresses the issue of professionalization of prevention in school environment as a key topic looked into by the disciplines whose force field is risk behaviour prevention. It addresses the topic from the perspective of current studies, making comparison with experience from the Slovak environment and with challenges set by so called General Educational Programs. A self-standing challenge for the improvement of theory and practice consists in the education of the teachers dealing with prevention. Finally, the article sets the challenges to be addressed with respect to professionalization of prevention in school environment in relation to the actual teachers implementing the prevention, to legislative stipulation of prevention (including a potential profession of social educator), but also to coordination of prevention with other entities.
\end{abstract}

\section{Keywords}

risk behaviour prevention, professionalization, education, social educator

\section{Introduction}

Helping professions have been experiencing a considerable boom since the 1990s in connection with the social order on an increase of quality of their activities professionalization. In the course of time, the need of professionally prepared workers active in social-educational work has been growing. Such professionals include graduates from the disciplines of social pathology and prevention, social work, social pedagogy, addiction research, medical disciplines, law, psychology, special pedagogy (ethical pedagogy) and others. All the above stated disciplines have their own topics of 
interest; nevertheless, their common force field can be found just in the area of social prevention and inclination towards prophylaxis and therapy of risk behaviour. Thereby a new phenomenon of inter-transdisciplinarity emerges.

\section{How can we perceive the term "prevention"?}

The term "prevention" comes from the Latin preavenire, praevenio (Šenková, 2002, p. 262). "The term is often used also in common life and we can define it as a set of measures to prevent an undesirable phenomenon like diseases, drug addictions, crimes, accidents, failure at school, social conflicts, etc." (Prague Centre of PP, 2015). Radimecký (2012) presents an interesting perspective relying upon splitting the word "prevent" into its prefix "pre-" and root "-event-". So the meaning of the term can be perceived as unified and clear. Pedagogy understands prevention in compliance with this meaning. The pedagogical dictionary written by Průcha, Walterová and Mareš (2013) describes prevention as a set of measures aimed at prevention of undesirable phenomena, particularly diseases, damages, socially pathological phenomena, and Miovský (2010, p. 24) adds that "it includes all types of upbringing, educational, health care, social or other interventions aimed at prevention of occurrence of risk behaviour, forestalling its further progression, mitigating the existing forms and manifestations of risk behaviour or helping to solve its consequences."

The actual professionalization of risk behaviour prevention can be perceived as the improvement of the issue in all its scope - efforts for legislative stipulation of prevention, of preventists, including their placement in the catalogue of professions, creation of a profession chart, seeking of ways for their motivation and funding of prevention. Furthermore, seeking of ways for better education in the issue, publication activities, implementation of research, methodical procedures, etc.

\section{Risk Behaviour Prevention in Current Studies}

Numerous studies show that the situation of occurrence of risk behaviour manifestations among children and youth in the Czech Republic is still not satisfactory (compare Blatný, 2006; Emmerová, 2011; Kokkevi, 2006; Kratěnová, 2007; Orosová et al., 2009). The issue of risk behaviour manifestation is extensive; their prevention requires primarily systemic approach, comprehensiveness, timeliness and flexibility. High-quality pedagogical preparation has a crucial share in application of social prevention (compare Bělík, 2012; Hroncová \& Emmerová, 2004; Kraus \& Bělík, 2011; Miovský, 2010). The issue under research is further reflected by current studies like Hroncová (2010), Emmerová (2010), Jusko (2010), Kosová \& Porubský (2011), Hroncová (2015), Miovský (2014), Hrubá, 2004; Kratěnová, 2007; Pelcák, 2012; Bělík \& Pelcák, 2013 a 2014; Hoferková, 2013; Kraus, 2003, 2014 and many others.

There are not many dedicated studies dealing with the issue of professionalization of risk behaviour prevention in the Czech environment. But there are several exceptions. 
They include the GAČR study No. 406/09/1220 Determination and development of competences of social educator in preparation, implemented by Š. Chudý. Very active and valuable are the studies implemented by the Clinic of addiction research, e.g. the VYNSPI II. Project - Implementation and evaluation of the minimal preventive program, systemic tools in education and creation of a collective system in the area of risk behaviour prevention for employees of schools and school facilities at state-wide level and others. In 2012, the author of this article implemented a specific study, MŠMT 2012 - Analysis of the issue of risk behaviour in pre-gradual preparation of teachers (Bělík, 2012) and the research plan called Comprehensive analysis of youth in South Bohemian Region, led by Blahoslav Kraus.

In the Slovak Environment, such studies included VEGA No. 1/0168/12 Professionalization of prevention of social-pathological phenomena in school environment in the Slovak Republic from the perspective of the social educator profession - current situation, problems and comparison with foreign countries, and KEGA No. 028UMB 4/2012 Preventive socialeducational work at secondary schools from the perspective of social educator.

At present, the author's working centre is implementing a study dealing with the issue of risk behaviour, including interviews with elementary school teachers on different topics related to risk behaviour prevention manifestations. Within the study, elementary school teachers were asked about the trends observed by them in the school environment in the issue of risk behaviour and its prevention.

\section{Which are the trends in the issue of risk behaviour prevention at the schools under research?}

Table No. 1 Trends in the issue of risk behaviour at the elementary schools under research from the perspective of elementary school teachers $N=164$

\begin{tabular}{|c|c|c|c|}
\hline $\begin{array}{l}\text { Trends in the issue of risk behaviour at larger } \\
\text { elementary schools }\end{array}$ & $\mathrm{n} 1$ & $\begin{array}{l}\text { Relative } \\
\text { frequencies }\end{array}$ & $\begin{array}{l}\text { Accumulative } \\
\text { frequencies }\end{array}$ \\
\hline $\begin{array}{l}\text { Increasing number of the phenomena addressed } \\
\text { at our school }\end{array}$ & 31 & 0.19 & 31 \\
\hline $\begin{array}{l}\text { Increasing aggression and self-confidence of children, } \\
\text { but also of parents }\end{array}$ & 19 & 0.12 & 50 \\
\hline Lack of parents' interest in their children & 16 & 0.10 & 66 \\
\hline $\begin{array}{l}\text { Higher incidence of bullying in form of psychological } \\
\text { bullying and cyberspace-related bullying }\end{array}$ & 13 & 0.08 & 79 \\
\hline Increasing amount of vulgar language among children & 11 & 0.07 & 90 \\
\hline $\begin{array}{l}\text { Problems in communication with parents - low } \\
\text { support in cooperation with them (uncritical excusing } \\
\text { of children) }\end{array}$ & 10 & 0.06 & 100 \\
\hline
\end{tabular}




\begin{tabular}{|l|c|c|c|}
\hline $\begin{array}{l}\text { Trends in the issue of risk behaviour at larger } \\
\text { elementary schools }\end{array}$ & $\mathrm{n} 1$ & $\begin{array}{c}\text { Relative } \\
\text { frequencies }\end{array}$ & $\begin{array}{c}\text { Accumulative } \\
\text { frequencies }\end{array}$ \\
\hline Greater social differences among children & 8 & 0.05 & 108 \\
\hline $\begin{array}{l}\text { Increasing among of hidden truancy covered } \\
\text { by parents }\end{array}$ & 7 & 0.04 & 115 \\
\hline Higher information of teachers about risk phenomena & 29 & 0.18 & 144 \\
\hline $\begin{array}{l}\text { More institutions and organizations offering } \\
\text { helping hand }\end{array}$ & 12 & 0.07 & 156 \\
\hline Generally less habit-forming substances & 3 & 0.02 & 159 \\
\hline Reduced incidence of manifestations of bullying & 3 & 0.02 & 162 \\
\hline Better communication with parents & 2 & 0.02 & 164 \\
\hline
\end{tabular}

The perspective of teachers of larger elementary schools shows two trends that can be defined based on Table No. 1.

The first trend consists in general increase of the phenomena shown in all items marked with dark grey colour. Additionally to the self-standing item defining the increasing phenomena (31), they include primarily the increasing aggression (19), lack of parent's interest in their children and bad communication of school and family $(16+10+7)$, vulgar language and excessive self-confidence (11); there are also higher social differences identified as a serious risk phenomenon by the teachers (8).

Another trend consists in increasing interest of the actual schools in the issue of risk behaviour and its prevention. 28 teachers answered to feel to be considerably better informed about risk phenomena at school and about the opportunities for their prevention. 12 answers included the information that the teachers perceive that there are more institutions offering a helping hand.

While the first trend is alarming, but expectable in the context of the research and awareness of pedagogical reality, the second trend can be perceived as promising for practice.

\section{Which tasks does the school have in risk behaviour prevention?}

A key role in risk behaviour prevention rests primarily on the family, but its role is often very problematic in these days (Kraus, 2014). The school is in another situation, as it has more tools at present. In the 1990, new trends started emerging in the school environment; we can describe them as non-violent penetration of non-specific prevention into the school environment. Schools of alternative type (Montessori, Freinet, Waldorf, Dalton and others) started emerging and they can be characterized as schools supporting nonspecific prevention. But there is only a minimal amount of such schools in the Czech environment. An overwhelming majority of children attend "common" schools for which 
many teachers use the slangy term "factories" - this term reflects long lasting efforts to save many and thus to increase the numbers of pupils in the classrooms. The numbers of children often remain at the upper limit; schools with 800 and more pupils are not an exception. Teachers often teach in classes in which there are many children with specific educational, but also upbringing needs and problems that would deserve a specific approach. Even a maximal teachers' effort can hardly succeed in such conditions. (Bělík \& Kraus, 2011)

The above stated facts lead us to deal with non-specific prevention, as we consider it essential in the long term. Such prevention is often primarily understood as an effort to offer a broad range of different leisure time activities to keep the children busy in the spirit of the saying "children who pay don't misbehave". But we must draw on the fact that the best prevention consists in installing a "moral cop" in the child's head. Something that prevents using the intellect, wit, strength for socially deviant behaviour. (Večerka, 2005) The school must be both formal and informal centre of such non-specific prevention (Pelcák, 2007). The formal aspect consists of several areas - for example, the school must successfully and actively manage communication in case of emerged or potentially emerging upbringing problems (in the moment, it could be assisted by the Timely Intervention System); and there should be a natural effort to communicate with other institutions - socialization agents.

\section{Prevention in Current Changes of the School Curriculum}

The school should also be the initiator and realizer of prevention programs. At present, we can often see that the school is the user of preventive custom-made programs provided by someone skilful, often for an attractive remuneration. The school should, thanks to its School Educational Program (hereinafter referred to as "SEP"), force its teachers to acquire such education and prepare such conditions for them that they become able to engage in prevention of social deviations themselves. School can be perceived as an informal centre of non-specific prevention, according to the study made by E. Walterová (1994) who writes about so called school hidden curriculum - i.e. everything the school radiates at a distance, everything that can be seen by us as inhabitants of the community, without examining the school in more detail. The hidden curriculum consists not only of the mutual behaviours among people, but also of what is called company culture in commercial sphere, i.e. of the way of organization of activities, of the amount and quality of processing of the activities implemented and of the media presentation, a thing schools are often completely missing (Walterová, 1994). Such "company culture" can of course include also high-quality pedagogical education of teachers, including the issue of prevention.

The educational effort can in no case consist only in passing of knowledge and in the implementation of the educational process (Bělík \& Šindelková, 2012). It should reach the whole personality in the sense of development and formation of character. It 
concerns the development of social competences, i.e. the person's ability to exist and succeed in the life of the society, in social structures at the level of family, job, local and broader community and to properly meet the respective roles. Such process can be described as social-upbringing action (personality-social development). This activity puts emphasis on creation of social skills allowing and enabling the person's life in the society (social communication, adaptation, establishing of contacts, development of optimal interpersonal relations).

An important step in supplementing the educational efforts with a pro-social aspect consisted in introduction of the General Educational Programs, or of School Educational Programs, respectively, with a character adapted to the situation in the specific school. The teachers' efforts in this area get a support tool in form of ethical education that has been introduced in schools as a self-standing subject already. Ethical education serves as a preventive factor aimed at compensating the drawbacks of socialization factors acting upon children and at developing positive social skills that should be mastered by each individual. Ethical education leads the pupils primarily to establish and maintain satisfactory relations, to develop a true picture of themselves, to solve creatively everyday problems, to formulate their opinions and attitudes based on their own judgement, under use of the results of discussion with others, to perceive critically the influence of models at developing their own world view, to understand the basic environmental and ecological issues and contexts of the modern world. According to the reflection of the teachers (Štastná \& Hoferková, 2009), pupils like the subject primarily thanks to the fact that the teachers prefer another teaching style - they primarily make use of the experience method, dramatization, work with stories, etc. The pupils can discuss during the lessons, acquiring information about themselves and about others, working in a stress-free atmosphere, they can experience success...

However ethical education, highlighted by us as a new school subject, is a part of a broader context that should serve as support to teachers. That context consists of the General Educational Programs, or the School Educational Programs (SEPs), much more familiar to teachers.

The education towards desirable values is present also within so called cross-sectional topics and in lessons aimed at acquisition of key competences. Here, it is not a secondary product of teaching of the contents of individual subjects any more, but a self-standing topic (although "education towards values" is not explicitly stated). This applies to the following expected outputs of cross-sectional topics: personality and social education (it leads to become aware of the value of cooperation and help, to become aware of the value of diversity of people, opinions, approaches to solution of problems; it contributes to become aware of moral dimensions of different human behaviours); education of democratic citizen (it contributes to develop values like justice, freedom, solidarity, tolerance and responsibility; it motivates to consideration and to readiness to help weaker individuals); education towards thinking in European and global context (it develops positive attitudes to otherness and cultural diversity; it supports positive attitudes to traditional European values); multicultural education (it stimulates, influences and 
corrects behaviours and value system of pupils; it teaches them to perceive dissimilarity as an opportunity for enrichment; it leads to engagement in fighting manifestations of intolerance, xenophobia, discrimination and racism); and environmental education (it contributes to development of healthy life style and to perception of aesthetic values of the environment; it leads to a receptive and sensitive approach to nature and to natural and cultural heritage) (Kraus \& Bělík, 2011).

\section{What are the potential ways to improve the implementation of prevention in school environment?}

One of the essential problems we see in the issue of implementation of the curricular reform consists in the teachers' readiness for such steps. For long years, teachers have been prepared primarily in the professional, specialized area. But newly, they are required to work with key competences (capabilities), which are an unusual area to many of them and they often approach professionals in the school environment to transfer the work in the area of risk behaviour prevention to them. In the Czech school environment, such professionals include the school prevention methodist, upbringing advisor, school psychologist, special teacher, or possibly the upbringing commission including the school direction, as well as cooperation with external subjects.

In connection with the previous studies of the author of this article (compare Berlík, 2012, 2015), we take the liberty to state that a great part of risk behaviour prevention should consist in non-specific work of the form teacher and of other teachers who have much more frequent contacts with the class and with the children in it than the above stated professionals can have. They can highlight positive behaviours under use of examples from their subjects; they can offer examples to direct the children to the way towards positive value orientation, etc. Another problem evident in the professionalization of risk behaviour prevention consists in the low level of independent university preparation of risk behaviour prevention professionals who subsequently enter schools. They include primarily the school prevention methodist and the upbringing advisor who are in charge of professional handling of the issue of risk behaviour prevention at schools. Among other things (e.g. financial and methodical problems), we see two closely related essential problems here. The first problem consists in the often low level of qualification of such professionals; and the second problem consists in low degree of the schools' motivation to deal with this issue and to care for the development and creation of conditions for a dignified work of such professionals. It often happens that the function of upbringing advisor or prevention methodist is a complementary function serving to "complete the workload" of some of the teachers. It is obvious that in such case, the professional cannot carry out his or her job with enthusiasm, zeal and qualified view.

In a situation characterized by problems in implementation of risk behaviour prevention in school environment, the discussion about a potential conceptual change should urgently continue. Based on qualified professional analysis of the situation (e.g. at the 
Socialia 2014 conference) and on comparison with the situation in neighbour countries, the model presented in Slovakia - i.e. social educator in school environment - seems the most adequate solution. The model includes a specially trained professional who replaces the above stated functions in the school environment and performs his or her profession as a specialist. In spite of repeated attempts, the profession of social educator is not as stipulated in the Czech legislation as it would deserve. In the 1990s and subsequently repeatedly after 2000 , attempts were made to include the profession of social educator in the Act of pedagogical workers according to the Slovak model. All attempts in that sense failed; nevertheless, the respective activities are still alive. A significant contribution, deserving great acknowledgement, constitutes the establishment and activities of the Association of Educators in Social Pedagogy, represented by J. Hladík. The document supporting the amendment of Act No. 563/2004 Coll., on pedagogical workers, as submitted in 2014 to the legislators, presented the social educator as a profession related primarily to the school environment (Hladík et al., 2014):

The social educator performs direct social-pedagogical activities at schools and in school facilities. Social-pedagogical activities are defined as educational, enlightening, socially educational, preventive, supportive, re-educational, consulting, diagnostic, coordination, organizational and expert activities implemented within schools, school facilities and social service facilities. They are aimed at comprehensive development of favourable conditions for social-educational actions of schools, school facilities and social service facilities, at support of processes of socialization and re-socialization of children and young people from endangering, neglecting, non-stimulating and otherwise disadvantaged environment and at tertiary socialization and re-socialization of adults.

The social educator performs the following activities at schools and school facilities:

- Educational and enlightening activities (implementation of educational and enlightening programs and projects focused on pupils, teachers, family and community).

- Social-upbringing and preventive activities (implementation of upbringing and preventive activities directed towards increasing social skills of pupils, towards development of their healthy life style, prevention of social exclusion, xenophobia, racism, etc.).

- Supporting, intervention and protective activities (provision of support in difficult life situations to pupils and their families, support of pupils from national minorities, interventions when children and young people are endangered by social-pathological phenomena, etc.).

The above stated argumentation was inspired and supported also by the study of the author of this article who interviewed elementary school teachers of small schools with less than 90 children $n_{1}$ and larger schools $-n_{2}$ ) and secondary schools (secondary vocational schools $n_{3}$ and grammar schools $n_{4}$ ) with respect to their opinion on introduction of social educator into the school environment. 
Table No. 2 Opinion of elementary school teachers on introduction of position of social educator into school environment

\begin{tabular}{|l|c|c|c|c|c|c|}
\hline & $n_{1}$ & $\begin{array}{c}\text { Relative } \\
\text { frequencies }\end{array}$ & $\begin{array}{c}\text { Accumulative } \\
\text { frequencies }\end{array}$ & $\mathrm{n}_{2}$ & $\begin{array}{c}\text { Relative } \\
\text { frequencies }\end{array}$ & $\begin{array}{c}\text { Accumulative } \\
\text { frequencies }\end{array}$ \\
\hline NO & 31 & 0.28182 & 31 & 2 & 0.2 & 2 \\
\hline YES & 79 & 0.71818 & 110 & 8 & 0.8 & 10 \\
\hline
\end{tabular}

Additionally, a goodness-of-fit test - chi square - was carried out to ascertain whether there is relation between the size of the school and the answers. The above stated facts show that teachers present their answers without relation to the size of their school. chi-square $=0.308$ degrees of freedom $=1$ probability $=0.579$

Table No. 3 Opinion of secondary school teachers on introduction of position of social educator into school environment

\begin{tabular}{|l|c|c|c|c|c|c|}
\hline & $n_{3}$ & $\begin{array}{c}\text { Relative } \\
\text { frequencies }\end{array}$ & $\begin{array}{c}\text { Accumulative } \\
\text { frequencies }\end{array}$ & $\mathrm{n}_{4}$ & $\begin{array}{c}\text { Relative } \\
\text { frequencies }\end{array}$ & $\begin{array}{c}\text { Accumulative } \\
\text { frequencies }\end{array}$ \\
\hline NO & 7 & 0.23 & 7 & 9 & 0.3 & 9 \\
\hline YES & 24 & 0.77 & 31 & 21 & 0.7 & 30 \\
\hline
\end{tabular}

Additionally, a goodness-of-fit test - chi square - was carried out to ascertain whether there is relation between the type of the school and the answers. The above stated facts show that teachers present their answers without relation to the type of their school (grammar school $x$ secondary vocational school)

chi-square $=0.434$

degrees of freedom $=1$

probability $=0.510$

The following list inspires to select answers of the interviewed teachers for argumentation:

- The school prevention methodist and upbringing advisor are swamped with work, they often don't manage to solve the problems; additionally, they are teachers themselves

- Risk behaviour occurs at an increasing degree at schools; therefore such professional becomes necessary

- I agree with this opinion, but such professional should partially teach in order to learn to know the children better

- Yes - but external cooperation would suffice as needed 
- I perceive such position as indispensable for larger schools, in combination with a school psychologist.

- Such professional would devote all time to children - at present, the situation is schizophrenic. Both the upbringing advisor and the school methodist are simultaneously teachers and they don't have time enough to meet their duties.

- It is often very challenging to cover the issue - an expert, specialist would come in handy.

- I propose such person should be a full-time specialist.

- Intensive cooperation with a professional would be beneficial.

- Then the teachers would have enough time for teaching.

- I have experience from Slovakia and France where a similar model exists.

- Such professional would manage individual and group work with children at a specialized level.

- The teachers could deepen their speciality and would have an expert on risk behaviour available.

\section{Teachers' arguments against employing a specialist:}

- A school advisory centre works well at our school. We don't see a need to have another employee.

- If such employee doesn't teach, he or she cannot know the overall context of children's life and problems.

\section{So how can we perceive the ways for professionalization of prevention in the school environment in summary?}

The actual professionalization of the issue of risk behaviour prevention in the school environment can be implemented through two possible ways:

The first of them would consist in the current situation of implementation of risk behaviour prevention at schools. Additionally to the responsibility of the school direction, prevention is under responsibility of a trained professional - school prevention methodist or upbringing advisor, school psychologist, special educator. As the available studies (Kraus \& Bělík, 2011) sufficiently describe, such fragmentation of competences among several responsible persons, who are also differently motivated and pregradually prepared for their work, often leads to a very dismal situation in risk behaviour prevention at schools. The salvation is often handled by external entities delivering programs of risk behaviour prevention to schools. Such external subjects (NNO) employ very well trained professionals - often graduates from socially oriented branches.

A second way can consist in finding a time-tested model that already works well abroad - i.e. in accepting the profession of social educator in school environment.

But such model faces missing legislative stipulation. At present, the Czech school environment experiences quite a strong pressure on the issue who will provide the 
prevention from professional aspect. From the perspective of social pedagogy, the social educator claims that environment. But special pedagogy already has the accredited discipline called Special pedagogy in teacher form, including the following graduate's profile: A pedagogical worker professionally prepared for work of special educator, upbringing advisor and school prevention methodist. At present, social work as a discipline presents the logical argument of a large amount of social problems emerging in the school environment and exceeding the teachers' competences. Therefore the demand on having a social worker in the school environment emerges.

So we can see the following ways for professionalization of prevention in the school environment:

- Better legislative stipulation of staffing specification of prevention actors.

- Improvement of pregradual preparation not only of professionals in branches with social-pedagogical orientation but primarily of teachers, including lifelong education.

- Development of a method of social-upbringing actions and creation of methodologies for individual risk behaviour phenomena.

- Improvement of mutual communication of professional and academic communities in the context of interdisciplinarity.

- Implementation of more research in the issue.

- Creation of a competence model of the "preventist" including the related profession chart.

- Giving publicity, in a positive meaning of the word, to the issue of risk behaviour prevention, with emphasis on positive values and models.

\section{Conclusion}

The issue of professionalization of risk behaviour prevention is not a simple topic. We can describe it as an interdisciplinary topic and also as a topic appropriated by several related disciplines. It is an issue not supported by a self-standing act (e.g. act on prevention) or by a ministry (unlike social work, to give an example). But it is important to open, address, discuss, research the topic of professionalization of prevention, to try to captivate students of pedagogical and social disciplines, but primarily to be active in this area. I believe that this article will constitute a valuable contribution to delimit this issue in the Czech environment.

\section{References}

Bělík, V., \& Šindelková, K. (2012). Problematika preventivně výchovného působení ve vzdělávání učitelů na českých pedagogických fakultách. [Problems of Preventive Educational Influence in Teacher Education at Czech Faculties of Education]. Prevence úrazů, otrav a násili [Prevention of Injuries, Intoxications and Violence], 12(12), 174-181. 
Bělík, V. (2012). Rizikové chování a jeho prevence v terciárním vzdělávání pedagogů. [Risk Behavior and its Prevention in Tertiary Education of Pedagogues]. Hradec Králové: Gaudeamus.

Bělík, V. (2015). Three perspectives on social pathology. Social Pathology and Prevention, $1(2), 11-20$.

Blatný, M. (2006). Prevalence antisociálního chování českých adolescentů z městských oblastí. [The Prevalence of Antisocial Behavior Czech Adolescents from Urban Areas] Československá psychologie [Czechoslovak Psychology], 50(4), 297-310.

Emmerová, I. (2011). Aktuálne otázky prevencie problémového správania u žiakov $v$ školskom prostředí. [Current Issues of Prevention of Problem Behaviour among Pupils in the School Environment]. Banská Bystrica: Matej Bel University.

Emmerová, I. (2010). The social pedagogue at school and their cooperation with teachers in the Slovak republic. The New Educational Review, 22(3-4), 43-54.

Hladík, J., Kraus, B., Lorenzová, J., Öbrink Hobzová, M., \& Pospíšil, L. J. (2014). Zdưvodňující zpráva: Návrh na zařazení profese sociálního pedagoga do zákona č. 563/2004 Sb. o pedagogických pracovnících. [Substantiating Report: Proposal for Classification of the Profession of Social Pedagogue to the Act no. 563/2004 Coll. On Teaching Staff]. Asociace vzdělavatelů v sociální pedagogice [Association of Educators in Social Pedagogy].

Hoferková, S., \& Šimková, E. (2012). Systém prevence sociálněpatologických jevů ze strany veřejné správy. [Sociopathic Phenomena Prevention System by the Public Administration]. Prevence úrazů, otrav a násilí [Prevention of Injuries, Intoxications and Violence], 8(1), 66-74.

Hoferková, S. (2013). Možnosti prevencekriminality mládeževČeské republice. [Possibilities of Prevention of Youth Crime in the Czech Republic]. In Prevencia sociálnopatologických javov $v$ školskom prostredí a jej profesionalizácia. Mezinárodní vědecké sympózium konané 12. 11. 2013 v Banskej Bystrici [Prevention of Socially Pathological Phenomena in the School Environment and its Professionalization. International Scientific Symposium Held on 12 November 2013 in Banská Bystrica] (pp. 263-273). Banská Bystrica: Matej Bel University.

Hroncová, J., \& Emmerová, I. (2004). Sociálna pedagogika. [Social Pedagogy]. Banská Bystrica: Faculty of Education, Matej Bel University.

Hroncová, J. (2015). The socio-pedagogical thinking of J.A. Comenius as inspiration of social pedagogy. The New Educational Review, 39(1), 39-50.

Hroncová, J. (2010). Social pedagogy in the Slovak republic in theory and practise genesis and present state. The New Educational Review, 22(3-4), 55-66. 
Hrubá, D. (2004). Children Education Programmes of Smoking Prevention and the Specific Role of the Teacher. In Učitelé a zdraví [Teachers and Health], 6 (pp. 299-306). Brno: Paido.

Jusko, P. (2010). Selected educational - scientific research and inter profession reflections. The New Educational Review, 22(3-4), 67-80.

Kokkevi, A, Gabhainn, S. N, \& Spyropoulou, M. (2006). Early initiation of cannabis use: A Cross-national European Perspective. Journal of Adolescent Health, 9(5), 712-719.

Kosová, B., \& Porubský, Š. (2011). The development and transformation of the school system in the Slovak republic after the fall of the totalitarian regime from the aspect of educational policy, educational practise at the level of primary schools, and University preparation of teachers. The new Educational Review, 23(1), 19-52.

Kratěnová, J. (2007). Prevalence and risk factors of poor posture in school children in the Czech Republic. Journal of School Health, 7(1), 131-137.

Kraus, B., \& Bělík, V. (2011). Trendy preventivně výchovného působení v současné škole. Prevence úrazů, otrav a násili [Prevention of Injuries, Intoxications and Violence], 7(1), 62-67.

Kraus, B., \& Hroncová, J. (2010). Sociální patologie. [Social Pathology]. Hradec Králové: Gaudeamus.

Kraus, B. (2008). Role sociální pedagogiky v prevenci sociálně patologických jevů. [Role of Social Education in the Prevention of Socio-pathological Phenomena]. In Specializační vzdělávání ve školství - pojetí a rozvoj profesního zdokonalování vedoucích pracovníků, výchovných poradců a preventistů sociálně patologických jevů: sborník z 8 . konference s mezinárodní účastí při přiležitosti 15. výročí založení Centra dalšího vzdělávání PdF Ostravské univerzity v Ostravě (konané dne 24. 1. - 25. 1. 2008) [Specialized Education in Schools - Conception and Development of Professional Improvement of Executives, Educational Counselors and Socially Pathological Phenomena Preventists: Proceedings of the $8^{\text {th }}$ International Conference on the Occasion of $15^{\text {th }}$ Anniversary of the Centre of Continuing Education on Faculty of Education, University of Ostrava (held on 24.1.-25.1.2008)] (pp. 20-25). Ostrava: Ostrava University.

Kraus, B. (2014). Společnost, rodina a sociální deviace. [Society, Family and Social Deviance]. Hradec Králové: Gaudeamus.

Kraus, B. (2014). Základy sociální pedagogiky. [Basics of Social Pedagogy]. Prague: Portál.

Miovský, M. (2010). Primární prevence rizikového chování ve školství. [Primary Prevention of Risk Behavior in Schools]. Prague: SCAN Association.

Orosová, O. (2009). Health-related behaviour among adolescents and young adults. Košice: Equilibria s.r.o. 
Pelcák, S. (2007). Nespecifická prevence a psychologie zdraví. [Non-specific Prevention and Health Psychology]. Sociální patologie [Social Pathology] (pp. 344-350). Hradec Králové: Gaudeamus.

Pelcák, S. (2012). Rizikové chování v adolescenci z pohledu salutogeneze. [Risk behaviour in Adolescence from the Perspective of Salutogenesis]. In Rodina a sociálně patologické jevy. Sborník příspěvků z mezinárodní konference 4. - 5. zárí 2012 [Family and Socially Pathological Phenomena. Proceedings of the International Conference 4-5 September 2012] (pp. 131-142). Hradec Králové: Gaudeamus.

Pelcák, S., \& Bělík, V. (2014). Osobnostní faktory syndromu rizikového chování $\checkmark$ adolescenci. [Personality Factors of the Risk Behavior Syndrome in Adolescence]. In Sociálne ohrozenia detí a mládeže v XXI. storočí a možnosti ich prevencie. Zborník medzinárodných vedeckých štúdií [Social Dangers of Children and Youth in XXI. Century and Possibilities of Their Prevention. Proceedings of International Scientific Studies] (pp. 207-216). Banská Bystrica: Belianum.

Pražské centrum primární prevence. (2015). Rizikové chování-prevence. [Risky BehaviourPrevention]. [online]. Prague: CSS. http://www.prevence-Prague.cz/index.php/rizikovechovani-charakteristiky

Průcha, J., Walterová E., \& Mareš, J. (2013). Pedagogický slovník. [Pedagogical Dictionary]. Prague: Portál.

Radimecký, J. (2007). Prevence a adiktologie pro odborníky pracující v ústavní výchově a preventivně výchovné péči: učební podklady ke kurzu. [Prevention and Adictology for Practitioners Working in Institutional Care and Preventive Care: Teaching Materials for the Course]. Prague: Klinika adiktologie 1. lékařské fakulty, Univerzita Karlova a Všeobecná fakultní nemocnice $v$ Praze. [Adictology Clinic of the $1^{\text {st }}$ Faculty of Medicine, Charles University and General University Hospital in Prague].

Šenková, S. (2002). Latinsko-český, česko-latinský slovník. [Latin-czech, Czech-latin Dictionary]. Olomouc: Olomouc Publishing.

Štastná, J., \& Hoferková, S. (2009). Názory pedagogických pracovníků na etickou výchovu (vybrané výsledky výzkumného šetření). [Teaching Staff Opinions on Ethical Education (Selected Results of the Research)]. e-Pedagogium. 13(1), 66-74.

Večerka, K. (2005). Prevence jako stav ducha. [Prevention as a State of Mind]. In Vybrané problémy sociální patologie: sborník př́spěvků ze semináře sekce sociální patologie MČSS: Šlovice 20.-22. dubna 2005 [Selected Problems of Social Pathology: Proceendings of the Seminar of Social pathology Section of MČSS: Šlovice 20-22 April 2005] (pp. 165-168). Prague: Masarykova česká sociologická společnost, sekce sociální patologie [Masaryk Czech Sociological Society, social pathology section]. 
Walterová, E. (1994). Kurikulum: Proměny a trendy v mezinárodní perspektivě. [Curriculum: Changes and Trends in International Perspective]. Brno: Masaryk University.

\section{Author}

PhDr. Václav Bělík, Ph.D.

Faculty of Education, Hradec Králové University Department of Social Pathology and Sociology Rokitanského 62, 500 03, Hradec Králové, The Czech Republic vaclav.belik@uhk.cz 